\title{
"Determinants of interest rate spreads of conventional banks listed on the Indonesia Stock Exchange"
}

\begin{tabular}{|c|c|}
\hline AUTHORS & $\begin{array}{l}\text { Chandra Wijaya (D https://orcid.org/0000-0001-9313-8823 } \\
\text { Yunika Lucianna (D https://orcid.org/0000-0001-9402-0210 } \\
\text { Fibria Indriati (D) https://orcid.org/0000-0001-9906-9662 }\end{array}$ \\
\hline ARTICLE INFO & $\begin{array}{l}\text { Chandra Wijaya, Yunika Lucianna and Fibria Indriati (2020). Determinants of } \\
\text { interest rate spreads of conventional banks listed on the Indonesia Stock } \\
\text { Exchange. Banks and Bank Systems, 15(4), 69-79. } \\
\text { doi:10.21511/bbs.15(4).2020.06 }\end{array}$ \\
\hline DOI & http://dx.doi.org/10.21511/bbs.15(4).2020.06 \\
\hline RELEASED ON & Wednesday, 09 December 2020 \\
\hline RECEIVED ON & Saturday, 06 June 2020 \\
\hline ACCEPTED ON & Tuesday, 01 December 2020 \\
\hline LICENSE & $\begin{array}{l}(c) E Y \quad E \\
\text { This work is licensed under a Creative Commons Attribution } 4.0 \text { International } \\
\text { License }\end{array}$ \\
\hline JOURNAL & "Banks and Bank Systems" \\
\hline ISSN PRINT & $1816-7403$ \\
\hline ISSN ONLINE & $1991-7074$ \\
\hline PUBLISHER & LLC "Consulting Publishing Company "Business Perspectives" \\
\hline FOUNDER & LLC "Consulting Publishing Company "Business Perspectives" \\
\hline
\end{tabular}

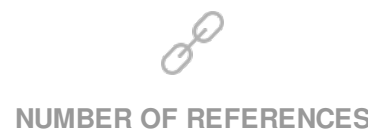

30
NUMBER OF FIGURES

1
NUMBER OF TABLES

5

(C) The author(s) 2023. This publication is an open access article. 


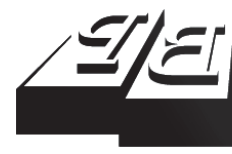

\section{BUSINESS PERSPECTIVES}

LLC "CPC "Business Perspectives" Hryhorii Skovoroda lane, 10, Sumy, 40022, Ukraine www.businessperspectives.org
Received on: $6^{\text {th }}$ of June, 2020 Accepted on: $1^{\text {st }}$ of December, 2020 Published on: $9^{\text {th }}$ of December, 2020

(c) Chandra Wijaya, Yunika Lucianna, Fibria Indriati, 2020

Chandra Wijaya, Ph.D., Professor, Department of Business Administration, Faculty of Administrative Science, Universitas Indonesia, Indonesia. (Corresponding Author)

Yunika Lucianna, Bachelor Researcher, Department of Business Administration, Faculty of Administrative Science, Universitas Indonesia, Indonesia.

Fibria Indriati, Ph.D., Assistant Professor, Department of Business Administration, Faculty of Administrative Science, Universitas Indonesia, Indonesia.
This is an Open Access article, distributed under the terms of the Creative Commons Attribution 4.0 International license, which permits unrestricted re-use, distribution, and reproduction in any medium, provided the original work is properly cited.

Conflict of interest statement: Author(s) reported no conflict of interest
Chandra Wijaya (Indonesia), Yunika Lucianna (Indonesia),

Fibria Indriati (Indonesia)

\section{DETERMINANTS OF INTEREST RATE SPREADS OF CONVENTIONAL BANKS LISTED ON THE INDONESIA STOCK EXCHANGE}

\begin{abstract}
The purpose of this study is to examine the variables that determine the interest rate spreads (IRS) of conventional banks listed on the Indonesia Stock Exchange (IDX). There are four major variables that affect a bank's interest rate spreads, namely financial bank, macroeconomics, economic freedom and market structure variables. The study participants are conventional banks listed on the Indonesia Stock Exchange from 2013 to 2017. Data was tested by using the OLS regression model. The results of this study show that all of the financial bank variables (Liquidity Risk (LR), Return to Asset Ratio (RTAR), Capital Adequacy (CA), Cost Efficiency Ratio (CER), and Risk Aversion (RA)) can significantly affect interest rate spreads. While of the macroeconomic variables, only two can significantly affect interest rate spreads, namely Gross Domestic Product (GDP) and Inflation Rate (IR). Furthermore, all of the variables of economic freedom and market structure can significantly determine interest rate spreads.
\end{abstract}

Keywords

economic freedom, financial bank variables, interest rate spreads, macroeconomic variables, market structure variables

JEL Classification $\quad$ E43, E44, G21

\section{INTRODUCTION}

Banking is one of the most important sectors of the economy of Indonesia, which is a bank-based country. A bank acts as an institution that performs the intermediation function of the fund from the public, which is channeled back in the form of a loan. The bank's intermediary activity presupposes the availability of interest rates paid to depositors, as well as interest rates on credits. The interest rate paid to depositors and the credit interest rate will form the spread or margin of interest rate. In general, interest paid to depositors is lower than interest charged to the borrower's funds (Tarus et al., 2012). According to Ho and Saunders (1981), positive bank interest rate spreads will always exist as long as the uncertainty related to bank transactions persists.

Studies on the variables affecting the interest rate spreads have been done by some previous researchers. Those studies outline the determinants of interest rate spreads with different country objects and time periods. Various determinants on spreads of interest rate can be categorized into four main variables, namely financial bank variables, macroeconomic variables, economic freedom variables and banking market variables. These four major variables have often been researched independently, but studies using the four are still rarely found. 
Conventional banking in Indonesia was chosen for several reasons. First, during 2013-2017, Indonesia had a problem with high rate spreads. Second, given the new rules and concerns of the Indonesia Financial Services Authority (OJK) regarding the interest rate spreads, it is worth noting which variables affect the value of the interest rate spread. By knowing the variables affecting the interest rate spread, the bank can find out the underlying problem that caused the high interest rate spread and determine the next step to lower their interest rate spreads using these variables. Henceforth, the analysis of the determinants of interest rate spreads can serve as a guide for policymakers and regulators in determining the strategy that should be adopted to stabilize the banking institution.

\section{LITERATURE REVIEW}

Interest rate spread is one of the most important tools for a bank. Interest rate spreads are related to the bank's efficiency rate and profitability. Thus, research on the variables affecting the interest rate spreads has been carried out in many countries. Here are some previous studies related to the variables affecting the spreads of interest rates.

Tarus et al. (2012) conducted a study of banking in Kenya during the period 2000-2009. Bank-specific, industry-specific, and macroeconomic variables were tested as the alleged determinants of interest rate spreads in the Kenyan banking system. Empirical research results show that credit risk and inflation have a significant positive impact on interest rate spreads, while economic growth and market concentration have significant negative effects. In the Kenyan banking, the negative relationship between market concentration and interest rate spreads may be due to high concentration of foreign banks with lower rate spreads. Thus, it can be said that markets with a high concentration of foreign banks will have a low interest rate spread due to better quality management or more efficient operations.

Research related to the variables determining the Indonesian banking interest rate spreads was also done by Sidabalok and Viverita (2011). The most influential factor of determinants and the spreads of Indonesian banking interest rates that have remained high ever since a few years ago was the rate spread of the previous period. This occurs due to the change in structural behavior caused by the financial crisis of 1997-1998 so that the bank pays attention to the principle of prudence and becomes more risk averse. In addition, some of the bank's specific variables that also affect the bank's rate spreads are high operational costs and lack of good management quality at the individual bank level. Market concentration relating to the bank's market strength has also a major influence on determining the bank's interest rate spreads, when banks with high market strength tend to have higher interest rate spreads.

Hawtrey and Liang (2008) conducted similar research in 14 OECD countries from 1987 to 2001. The study was conducted in different countries to explain the variables that determine interest rate spreads in general for the banking sector of these countries. According to the study, the scale effect variable and management efficiency have a negative influence on the banking interest rate spreads, while market strength, operational costs, risk aversion level, market interest rate volatility, credit risk, opportunity cost of the bank's reserves, and implicit interest payment all have a significantly positive impact on the interest rate spreads.

Research on the determinants of interest rate spreads in Chinese banking was conducted by Zhou and Wong (2008) between 1996 and 2003. In line with Ho and Saunders (1981), Zhou and Wong (2008) stated that the banking market competition structure had the biggest influence on determining bank's interest rate spreads. During the research period, the level of the Chinese banking market concentration showed a declining trend. This is due to increasing the number of banks in China and the existence of the World Trade Organization (WTO) agreement causing China's banking market to be open to foreign banks. In addition, some of the internal variables of a bank also affected some factors such as operational costs, bank management risk aversion level, transaction number, and payment of implicit interests to a depositor.

Maudos and Fernandez de Guevara (2004) conducted research on the variables that determine 
interest rate spreads by developing the model of Ho and Saunders (1981). The study included several European countries, namely Germany, Spain, Italy, France, and the United Kingdom during the period 1993-2000. In the model, Maudos and Fernandez de Guevara (2004) included bank operating costs explicitly. In addition, unlike usual practice in the literature, a direct measure of the level of competition (Lerner's index) in different markets is used. The results show that the decline in margins in the European banking system is in line with the relaxation of competitive conditions (increasing market strength and concentration), as this effect has been overcome by a reduction in interest rate risk, credit risk, and operating costs.

Valverde and Rodriguez-Fernández (2007) used the model developed by Ho and Saunders (1981) on a multi-output framework that tested several types of bank margins, not just the interest rate spreads. Their research was conducted in several European banking countries and showed that the market strength of a bank would be higher when the bank diversified its non-traditional activities to gain additional profit.

The banking system in a country certainly differs from other countries due to different macroeconomic environments, different tax policies, financial market conditions, and internal bank variables themselves. Demirgüç-Kunt and Huizinga (1999) conducted research on the determinants of the spread of interest rates in 80 different countries. In line with some previous studies, the bank's capitalization rate was positively related to the bank's interest rate spread, while the bank's reserves rate was negatively related to its interest margin. In addition, fluctuations in the bank's operational costs are reflected in the bank's rate spreads. Foreign banks in developing countries tend to have higher interest rate spreads compared to local banks since foreign banks have technological superiority. Macroeconomic variables also affect the variation taking place in the spread of the interest rate. Inflation and volatility in real interest rates have a positive effect on the spread of interest rates, as well as on the level of concentration in the banking market.

Based on the above literature and guidelines, the study uses them as a reference material, as there is information relevant to the research that needs to be done. In addition, theories and models used are expected to assist in conducting this research.

\subsection{Interest rate spreads}

The difference (spread) between the interest rate that banks charge on loans and the interest rate they pay on deposits is a key financial bank variable, since it indicates the level of efficiency in financial intermediation (Aydemir \& Guloglu, 2017). While other studies focus more on the determinant of the net interest margin, Aydemir and Guloglu (2017) select spreads as dependent variables in their investigations, as spreads are more easily affected and also respond faster to changes in the economic environment than interest income and expense. Bank's interest rate spreads are found in the following equations:

$$
\begin{aligned}
& \text { Interest Rate Spread }(\text { IRS })= \\
& =\frac{\text { Interest gained from Loans }}{\text { Total Loans }}- \\
& -\frac{\text { Interest paid to Deposits }}{\text { Total Deposits }} .
\end{aligned}
$$

\subsection{Determinants of interest rate spreads}

Many studies have revealed the variables that affect spread interest ratei. Referring to the results of the study by Shubiri and Jamil (2017), this study focuses on four main variables, namely financial banking variables, macroeconomic factors, economic freedom variables and market structure variables. Below is an explanation of each factor.

\subsubsection{Financial bank variables}

Previous research conducted by Shubiri and Jamil (2017) uses five variables related to financial bank variables affecting bank interest rate spreads, namely: Return to Asset Ratio (RTAR), Liquidity Risk (LR), Cost Efficiency Ratio (CER), Risk Aversion (RA) and Capital Adequacy (CA).

Valverde and Fernandez (2007) state that the Return to Asset Ratio (RTAR) provides information on the level of efficiency of the bank being run and shows 
how much profit is generated on average from its assets. Liquidity Risk (LR) is the risk caused is caused by the bank's inability to fulfill obligations that are due. The Cost Efficiency Ratio (CER) is a ratio used to measure how much non-interest costs a bank incurs to generate net interest income and other income other than interest income.

According to the results of research conducted by Entrop et al.(2015), Risk Aversion positively affects interest rate spreads. Capital Adequacy ratio (CA) is the ratio of bank performance to support assets that contain or generate risk, for example, loans. CA is an indicator of a bank's ability to cover the decline in its assets as a result of bank losses caused by risk assets.

Hawtrey and Liang (2008) conducted an inter-state research in 14 OECD countries and found a bank-specific variable that affected the significant and positive spreads of interest rates among other operational costs, risk aversion behavior, credit risk, loan volume and management quality. Stewart et al. (2015) conducted a study of the Vietnamese banking sector and found that the bank's size and ownership influenced the spreads of interest rates when large private banks were more efficient than government-owned and smallsized banks.

\subsubsection{Macroeconomic variables}

Aspects such as unemployment rate, debt service ratio, Gross Domestic Product (GDP) growth, inflation rate and principal repayment are mostly used as control variables across studies such as Shubiri and Jamil (2017), Perez (2011), and Beck and Hesse (2006). Shubiri and Jamil (2017) studied how macroeconomics variables affected nominal and real interest spreads in Oman. They found that the variation in economic cycles may cause the variation of the interest rate spreads across the region in Oman. As is the case with inflation and liquidity conditions, this study has also found that the discrepancy in the exchange rate regime affects the enormity of the spreads.

Variables such as the level of financial development, inflation, economic growth, volatility of interest or exchange rates, trade or budget deficits, or overall uncertainty surrounding macroeconomics performance affect the spread of banking at the aggregate country level. Inflation largely determines the most quoted interest margins among these macroeconomic characteristics (Raharjo et al., 2014; Crowley, 2007; Chirwa \& Mlachila, 2002). Banks will cover losses in profits by raising loan interest rates and expanding their interest margins. For this reason, banks will believe that borrowers will repay their loans.

On the other hand, economic growth was also caused by variables spreading banking. The result of increasing creditworthiness of economic actors will be an increase in the resources that banks can lend since they will receive more income and savings. Lower interest margins are a form of banks' reaction to situations that they consider favorable. One thing that must remain a concern is that the spread of banking will influence economic growth, including savings and investment (Kiptui, 2014). Demirgüç-Kunt and Huizinga (1999) found that the spread of banking and economic growth had a negative correlation. Other variables that influence interest margins are macroeconomic instability, interest rate volatility, exchange rates, growth rates, trade deficits, and budget deficits (Gelos, 2006). Legal and institutional variables are also considered to affect interest margin.

\subsubsection{Economic freedom variables}

Another factor affecting interest margins in a country is the quality of governance of a country itself. Apart from the factor of competition between banks, banks can also reduce risk premiums and interest margins if the level of corruption in that country is low (Demirgüç-Kunt \& Huizinga, 1999). La Porta et al. (2008) explained that the historical side of the legal framework in a country will determine the way an institution functions according to its economic performance.

The Fraser Institute and the Economic Freedom Network, the world's first institution to measure the index of economic freedom, have succeeded in producing and publishing the Economic Freedom of World Index (EFW Index). The EFW Index contains indicators of economic freedom in more than 100 countries around the world, including Indonesia. This index was built with five main components of the main assessment, namely: 


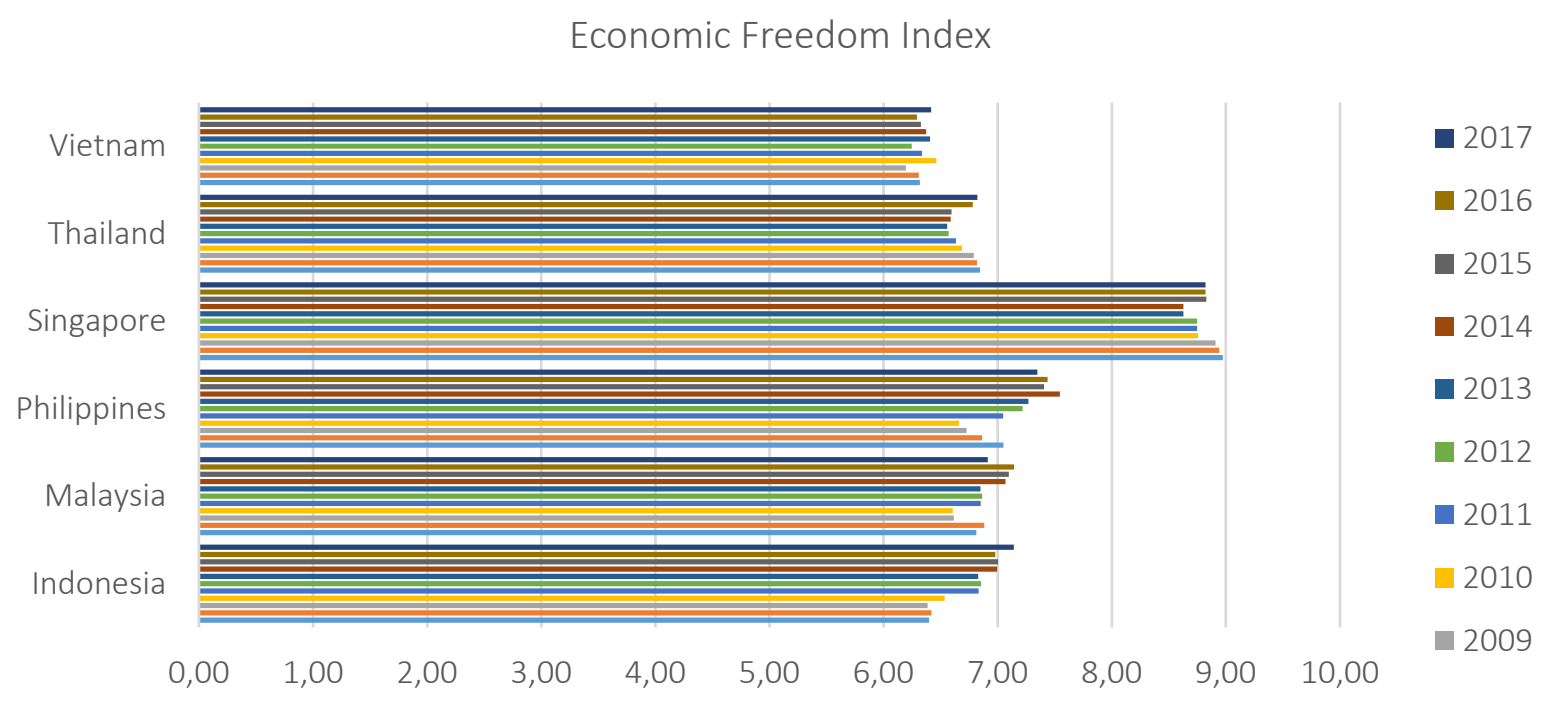

Figure 1. Economic Freedom Index 2013-2017

1) the size/system of government (Size of Government);

2) legal structure and security of property rights;

3) access to credit (Sound Money);

4) freedom of trade (Freedom to Trade Internationally), and

5) credit, business and labor rules (Regulation).

Over the past 14 years (1995-2008), the Fraser Institute has assessed the economic freedom of a country, with the top 40 countries in various parts of the world, 10 of which are still inhabited by developed countries. Hong Kong and Singapore always ranked 1st and 2 nd.

\subsubsection{Market structure variables}

As an industry, the analysis of the individual bank behavior is not detached from the market structure in which the bank operates. An analysis of competition and efficiency of banks usually leads to an analysis of banking microeconomics. This analysis can include bank behavior in price policy, such as deposit interest rate behavior and credit interest rates, as well as non-price competitions, such as banking product differentiation and service optimization to customers. The efficiency analysis is usually related to profit maximization, income maximization and/or minimum costs. In terms of Indonesia's economic growth, the research discusses the market structure and performance efficiency in the banking industry, assesses the size of the performance indicators of the banking sector to become the market leader.

Herfindahl-Hirschman Index (HHI) is the most widely used concentration measurement. HHI is a measure of the size of firms in relation to the industry and an indicator of the amount of competition between them (Naylah, 2010). It is defined as the sum of the squares of the market shares of the firms within the industry (sometimes limited to the 50 largest firms), where the market shares are expressed as fractions. The result is proportional to the average market share, weighted by market share. As such, it can range from 0 to 10,000 points, moving from a huge number of very small firms to a single monopolistic producer.

HHI takes into account the relative size and the number of banks operating in the banking industry. It can be assumed that $\mathrm{HHI}$ has a value of 10,000 points, which means that there is only one bank operating in the banking sector (a monopoly structure), and if 0 it means that there is a large number of banks in the banking industry of same size. An increase in HHI indicates a decrease in competition and an increase in market power in the Indonesian banking industry, while a decrease indicates the opposite. 


\section{RESEARCH METHODOLOGY}

\subsection{Data and sample}

This study applied a quantitative approach with correlational study. Correlational study attempts to find the relationship between two or more variables (Sekaran \& Bougie, 2013). The study participants are conventional banks listed on IDX. Data were retrieved from the site www.idx.co.id; the data were obtained in the form of IDX 20132017 financial statements. The object in this study was a banking company on Interest Rate Spreads (IRS) on the Indonesia Stock Exchange in 2013-2017.

\subsection{Variables and the research equation model}

The independent variables of this study include financial bank variables, macroeconomic variables, economic freedom variables and market structure variables; IRS is a dependent variable. The data was analyzed using the Ordinary Least Square (OLS) regression model. OLS method is a method of multiple regression analysis aimed at determining the impact of independent variables on dependent variables. The OLS method will produce the best estimate compared to other methods if all classical assumptions are met. Conversely, if the classical assumptions are not met, it will result in a bad estimate.

The selection of these variables is based on previous research, which is almost the same. Since the nature of Indonesia's growing economy will make constant changes to the Indonesian market, two legal variables are added as market variables. These four groups of variables will be tested using the following four equations:

$$
\begin{aligned}
& \text { Interest Rate Spreads }(\text { IRSit })= \\
& =\alpha 0+\beta 1 \text { RTARit }+\beta 2 \text { LRit }+ \\
& +\beta 3 \text { CERit }+\beta 4 \text { RAit }+\beta 5 \text { CAit }+€ i t,
\end{aligned}
$$

$$
\begin{aligned}
& \text { Interest Rate Spreads }(\text { IRSit })= \\
& =\alpha 0+\beta 1 U R i t+\beta 2 D S R i t+ \\
& +\beta 3 \text { GDPit }+\beta 4 \text { IRit }+\beta 5 \text { PRit }+€ i t,
\end{aligned}
$$

$$
\begin{aligned}
& \text { Interest Rate Spreads }(\text { IRSit })= \\
& =\alpha 0+\beta 1 \text { SOGit }+\beta 2 \text { LSPRit }+ \\
& +\beta 3 \text { SMit }+\beta 4 \text { FTIit }+\beta 5 \text { Rit }+€ i t \\
& \text { Interest Rate Spreads }(\text { IRSit })= \\
& =\alpha 0+\beta 1 \text { HHIit }+€ i t .
\end{aligned}
$$

The independent variables used in this study are grouped as follows:

1) Financial bank variables - Return to Asset Ratio (RTAR), Risk Aversion (RA), Liquidity Risk (LR), Capital Adequacy (CA), and Cost Efficiency Ratio (CER);

2) Macroeconomic variables - Inflation Rate (IR), Unemployment Rate (UR), Gross Domestic Product (GDP), Debt Service Ratio (DSR), and Principle Repayment $(P R)$;

3) Economic freedom variables - Legal System and Property Rights (LSPR), Size of Government (SOG), Sound Money (SM), Regulation $(R)$, and Freedom to Trade Internationally $(F T I)$;

4) Market structure variable - HerfindahlHirschman Index $(H H I)$.

According to Tarmidzi and Kusumo (2003), financial bank variables are tools used to get an idea of the underlying conditions. Financial ratio is appropriately inter-coordinated to identify areas requiring further investigation. Ratio analysis can reveal important relationships and base comparisons in finding conditions and trends that are difficult to detect by studying each of the components that make up the ratio. Like other analysis tools, the most useful ratio is when it is oriented forward. This means that we often adjust the variables that affect the ratio between possible trends and their future size. Also, it is necessary to assess variables that can potentially affect the ratio in the future. Since the usability ratio depends on its implementation and inter-performance skills, it is the most challenging part of the ratio analysis.

The following is the calculation of financial measures: 
- $\quad$ Liquidity Risk

$($ LR $)=$ Deposits $/$ Liabilities

- Return to Asset Ratio

$($ RTAR $)=$ Income/Assets

- Risk Aversion

$(R A)=$ Equity $/$ Total Assets

- Cost Efficiency Ratio

$(C E R)=$ Operating Cost/Total Income;

- Capital Adequacy

$(C A)=$ based on as $\%$ Total Regulatory Capital .

Macroeconomic variables represent an external variable consisting of important economic variables that affect each other and significantly contribute to the relationship with the spread of the interest rate. The increased unemployment rate due to lack of job opportunities resulted in a negative impact on GDP. On the other hand, the increased unemployment rate also raised government spending on infrastructure projects to create employment. This act has an impact on additional financial burden even in oil price fall, and also affects government revenues directing to additional service debt and repayment principles.

Economic freedom variables are measured in the index that shows the capability of the private sector to react and be agile toward national government and international regulations. This index also measures the capability of the business to contribute positively to the environment.

Table 1. Descriptive analysis
Data on variables of Macroeconomics and Economic Freedom were collected from the Annual Statistics Bulletin, Annual World Economic Freedom Report, Annual Company Guidelines from the central bank's annual statistical reports, world reports and company guidelines for the period from 2013 to 2017.

The HHI variable as a market structure variable is a value that compares a bank's ability to obtain a percentage of market capitalization. This HHI variable is obtained by calculating the number of squares of the bank market capitalization divided by the total market capitalization.

\section{FINDINGS AND DISCUSSION}

\subsection{Descriptive analysis}

Descriptive analysis is used to measure the central tendency of the data, namely minimum, maximum, average, and standard deviation of four variables used in this study (financial, macroeconomics, economic freedom, and market structure). In relation to a financial indicator, minimum and maximum costs, optimal minimum ratios, optimal minimum ratios, and greater minimum ratios are shown in Table 1. Jamil et al. (2015) found that the ratio of the net operating profit was signif-

\begin{tabular}{|c|c|c|c|c|}
\hline \multicolumn{5}{|c|}{ Source: Eviews 9 data processing result } \\
\hline Dependent and independent variables & Min & Max & Mean & Std. deviation \\
\hline Interest Rate Spreads (IRS) & 0.0156 & 0.1504 & 0.0665 & 0.0258 \\
\hline \multicolumn{5}{|c|}{ Financial bank variables } \\
\hline Liquidity Risk (LR) & 0.4202 & 1.4072 & 0.8469 & 0.1336 \\
\hline Risk Aversion $(R A)$ & 0.0520 & 0.6895 & 0.1525 & 0.0944 \\
\hline Cost efficiency Ratio (CER) & 0.3328 & 2.3520 & 0.9059 & 0.2215 \\
\hline Capital Adequacy (CA) & 0.0802 & 0.8749 & 0.1972 & 0.0790 \\
\hline Return to Asset Ratio (RTAR) & -0.1115 & 0.0514 & 0.0113 & 0.0221 \\
\hline \multicolumn{5}{|c|}{ Economic freedom variables } \\
\hline Legal System and Property Rights (LSPR) & 0.0451 & 0.0498 & 0.0470 & 0.1924 \\
\hline Size of Government (SOG) & 0.0772 & 0.0793 & 0.0779 & 0.0753 \\
\hline Freedom to Trade Internationally (FTI) & 0.0698 & 0.0735 & 0.0715 & 0.1459 \\
\hline Sound Money (SM) & 0.0913 & 0.0998 & 0.0948 & 0.3079 \\
\hline Regulation $(R)$ & 0.0616 & 0.0663 & 0.0632 & 0.1681 \\
\hline \multicolumn{5}{|c|}{ Macroeconomic variables } \\
\hline Gross Domestic Product (GDP) & -0.0463 & 0.0893 & -0.0513 & 0.0612 \\
\hline Unemployment Rate (UR) & 0.0405 & 0.1504 & 0.0663 & 0.0017 \\
\hline Debt Service Ratio (DSR) & 0.2036 & 0.0451 & 0.0423 & 0.0638 \\
\hline Principal Repayment $(P R)$ & -0.7404 & 2.1184 & 0.2844 & 0.0162 \\
\hline Inflation Rate (IR) & 0.0248 & 0.0544 & 0.0422 & 0.0102 \\
\hline \multicolumn{5}{|c|}{ Market structure based on market concentration } \\
\hline Herfindahl-Hirschman Index $(H H I)$ & 0.0610 & 0.0660 & 0.0640 & 0.0020 \\
\hline
\end{tabular}


icant to the improvement of the working capital management efficiency compared to earnings before interest and tax ratios. Among the economic variables, this variable has a large amount of detailed payment funds, which means that the banking sector has a system and protection to collect the principal amount of the loan extended and other costs. As for legal variables, all variables increase relative to what was issued by the government when considering the increase in the nation's index of economic freedom. The announced Herfindahl-Hirschman Index, which reflects market structure, has improved and developed over to the period, showing that the market achieves growth in most sectors.

\subsection{Determinants of the interest rate spread}

Based on the results of testing the four equation models used in the study, the following results were obtained.

\subsubsection{The impact of financial bank variables on IRS}

Based on the results of testing equation (1), Table 2 shows that all financial bank variables used in testing had an influence on IRS. RTAR, LR, CER and $R A$ variables also have a significant negative impact on IRS, while the variable $C A$ has a significant positive effect.

Table 2. The impact of each independent financial bank variable on IRS

Source: Data processed by the authors.

\begin{tabular}{l:c:c:c:c}
\hline Variable & Coefficient & Std. error & t-statistic & Prob. \\
\hline$R T A R$ & -0.191795 & 0.061671 & -3.109964 & 0.0022 \\
\hdashline$L R$ & -0.030460 & 0.014325 & -1.126280 & 0.0750 \\
\hdashline$C E R$ & -0.005477 & 0.005543 & -1.987962 & 0.0347 \\
\hdashline$R A$ & -0.207556 & 0.034262 & -6.057840 & 0.0000 \\
\hdashline$C A$ & 0.033824 & 0.015944 & 2.121436 & 0.0354 \\
\hdashline$C$ & 0.124500 & 0.014380 & 8.657864 & 0.0000 \\
\hline
\end{tabular}

Given the above research findings, it can be concluded that Indonesian banks will be able to reduce their IRS if they increase profitability (RTAR), reduce risk $(R A)$, have high liquidity $(L R)$, are able to achieve operational efficiency $(C E R)$ and overall capital adequacy declines.

\subsubsection{The impact of macroeconomic variables on IRS}

Based on the results of testing equation (2), Table 3 shows that not all microeconomic variables used in testing influence IRS. GDP and $I R$ variables have a significant and negative effect on IRS, while other variables (UR, $D S R$ and $P R$ ) have no significant effect.

The test results from equation (2) indicate to banking sector stakeholders in Indonesia that IRS will decrease if the GDP increases. Besides, IRS will also decrease if inflation rises. This may explain why an increase in IRS will force the Central Bank of Indonesia (Bank Indonesia) to raise the benchmark interest rate $(S B I)$. With $\mathrm{n}$ increase in the $\mathrm{BI}$ rate $(S B I)$, it will increase deposit rates, which, in turn, will increase interest rates on loans. Of course, this will burden the debtors if the bank still sets a high IRS. Then, the bank will inevitably lower its IRS.

Table 3. The impact of each independent macroeconomic variable on IRS

Source: Data processed by the authors.

\begin{tabular}{l|c|c|c|c}
\hline Variable & Coefficient & Std. error & t-statistic & Prob. \\
\hline$U R$ & 2.096302 & 1.404866 & 1.492172 & 0.1372 \\
\hline$D S R$ & -0.072942 & 0.044849 & -1.626399 & 0.1054 \\
\hdashline$G D P$ & -0.021922 & 0.007697 & -2.848099 & 0.0049 \\
\hdashline$I R$ & -0.813345 & 0.375698 & -2.164890 & 0.0316 \\
\hline$P R$ & 0.00155 & 0.003720 & 1.385464 & 0.1675 \\
\hline
\end{tabular}

\subsubsection{The impact of economic freedom variables on IRS}

Based on test results from equation (3), Table 4 shows that all economic freedom variables used in testing had an influence on IRS. SOG, SM and FTI all have a significant negative effect on IRS, while other variables ( $L S P R$ and $R$ ) have significantly positive effects.

Based on the research findings, it can be concluded that the Indonesian banking sector will only lower its IRS if the Indonesian government (SOG) enlarges its size in providing services to the public by increasing the government budget to provide better public services. In addition, IRS can also be reduced by banks in Indonesia if Bank Indonesia is able to stabilize the IDR currency $(S M)$. A de- 
Table 4. The impact of each independent economic freedom variable on IRS

Source: Data processed by the authors.

\begin{tabular}{|c|c|c|c|c|}
\hline Variable & Coefficient & Std. error & t-statistic & Prob. \\
\hline SOG & -0.066330 & 0.029853 & -2.221891 & 0.0274 \\
\hline$\angle S P R$ & 0.065873 & 0.026452 & 2.490269 & 0.0136 \\
\hline$S M$ & -0.086602 & 0.040193 & -2.154669 & 0.0324 \\
\hline FTI & -0.041273 & 0.016073 & -2.567842 & 0.0110 \\
\hline$R$ & 0.099132 & 0.045783 & 2.165278 & 0.0316 \\
\hline
\end{tabular}

Table 5. The impact of each independent market structure variable on IRS

Source: Data processed by the authors.

\begin{tabular}{l|c|c|c|c}
\hline \multicolumn{1}{c|}{ Variable } & Coefficient & Std. error & t-statistic & Prob. \\
\hline $\mathrm{HHI}$ & 0.000184 & $9.08 \mathrm{E}-05$ & 2.031021 & 0.0436 \\
\hline
\end{tabular}

cline in IRS can also happen if the private sector is given freedom by the Indonesian government to trade internationally, both for export and import FTI. On the contrary, IRS will increase if the government makes too strict measures in the legal system and property rights (LSPR) and sets other regulations $(R)$ in various existing business fields. In this case, the Indonesian government can help reduce IRS by deregulating various policies that impede business activities.

\subsubsection{The impact of market structure variables on IRS}

Table 5 shows the impact of market structure on interest rate spreads. Based on the OLS regres- sion, it shows that the commercial banking sector plays a significant role in the market. This role causes an impact on the country's economy. This plays an important role in the market, which has implications for the country's economic conditions. This shows that the interest rate spread is determined by the market and reflected in the determination of the interest rate spread based on market requirements, government care in the banking industry, and the demand and supply of banking facilities. Consequently, OJK must be able to create healthy and resilient Indonesian banks so that the number of existing banks is not too large (the market is increasingly concentrated), which will affect the decline in IRS.

\section{CONCLUSION}

Based on the results and analysis, the following conclusions are drawn: First, all financial bank variables affect interest rate spreads in conventional Indonesian banks. Second, not all economic variables that describe the macroeconomic situation in Indonesia and are represented by five variables, namely Gross Domestic Product (GDP), Debt Service Ratio (DSR), Unemployment Rate $(U R)$, Principle Repayment $(P R)$ and Inflation Rate $(I R)$, affect the size of the bank interest rate spread. Among economic variables, only GDP and $I R$ variables alone affect the amount of spread. Third, the economic freedom variables show how easily Indonesia can be used as a place for trade. Economic freedom is represented by five variables, including Legal System and Property Rights (LSPR), Size of Government (SOG), Freedom to Trade Internationally (FTI), Sound Money (SM), and Regulation $(R)$. All variables used affect the amount of bank interest rate spreads. Finally, market variables are based on concentration, which shows what influence a bank has on the market in generating profit, and this is represented by the Herfindahl-Hirschman Index (HHI). The result also shows that market concentration influences interest rate spreads. 


\section{AUTHOR CONTRIBUTIONS}

Conceptualization: Chandra Wijaya, Yunika Lucianna.

Data curation: Yunika Lucianna.

Formal analysis: Chandra Wijaya, Yunika Lucianna, Fibria Indriati.

Funding acquisition: Chandra Wijaya, Yunika Lucianna, Fibria Indriati.

Investigation: Chandra Wijaya, Yunika Lucianna.

Methodology: Chandra Wijaya, Yunika Lucianna.

Project administration: Fibria Indriati.

Resources: Chandra Wijaya, Yunika Lucianna.

Supervision: Chandra Wijaya.

Validation: Chandra Wijaya, Yunika Lucianna, Fibria Indriati.

Writing - original draft: Yunika Lucianna.

Writing - reviewing \& editing: Chandra Wijaya, Fibria Indriati.

\section{ACKNOWLEDGMENT}

The authors thank the Research Cluster of Governance and Competitiveness, Faculty of Administrative Sciences, Universitas Indonesia, for providing financial assistance and supporting materials related to discussion, and assistance in writing this paper.

\section{REFERENCES}

1. Aydemir, R., \& Guloglu, B. (2017). How do Bank Determine Their Spreads under Credit and Liquidity Risks during Business Cycles? Journal of International Financial Market, Institutions and Money, 46, 147-157. https://doi. org/10.1016/j.intfin.2016.08.001

2. Beck, T., \& Hesse, H. (2006). Bank Efficiency, Ownership, and Market Structure: Why are Interest Spreads so High in Uganda? (Working Paper No. 227). Retrieved from https://www.economics.ox.ac.uk/ materials/working_papers/paper277.pdf

3. Chirwa, E., \& Mlachila, $M$ (2002). Financial Reforms and Interest Rate Spreads in the Commercial Banking System in Malawi (IMF Working Papers No. WP/02/6). https://doi. org/10.5089/9781451842302.001

4. Crowley, J. (2007). Interest Rate Spreads in EnglishSpeaking African Countries (IMF Working Papers No. WP/07/101). https://doi. org/10.5089/9781451866650.001

5. Demirgüc-Kunt, A., \& Huizinga, H. (1999). Determinants of
Commercial Bank Interest Margins and Profitability: Some International Evidence. World Bank Economic Review, 13(2), 379-408. https://doi.org/10.1093/ wber/13.2.379

6. Entrop, O., Memmel, C., Ruprecht, B., \& Wilkens, M. (2015) Determinants of Bank Interest Margins: Impact of Maturity Transformation Journal of Banking and Finance, 54, 1-19. http:// dx.doi.org/10.2139/ssrn.2101815

7. Farid, H., \& Siswanto, S. (1998). Analisis Investasi dan Manajemen Portofolio. Edisi Pertama, BPFE, Yogyakarta.

8. Fraser Institute. (n.d.). Economic Freedom of the World (EFW). Retrieved from www.freetheworld. com

9. Gelos, R. G. (2006). Banking Spreads in Latin America (IMF Working Papers No. WP/06/44). Retrieved from https://www. imf.org/en/Publications/WP/ Issues/2016/12/31/BankingSpreads-in-Latin-America-18792

10. Hawtrey, K., \& Liang, H. (2008). Bank interest margins in OECD countries. The North American
Journal of Economics and Finance, 19(3), 249-260. https://doi. org/10.1016/j.najef.2008.07.003

11. Ho, T. S., \& Saunders, A. (1981). The Determinants of Banks Interest Margins: Theory and Empirical Evidence. Journal of Financial and Quantitative Analysis, 16(4), 581-600. https:// doi.org/10.2307/2330377

12. Indonesia Stock Exchange (IDX). (n.d.). IDX Data. Retrieved from https://www.idx.co.id/en-us

13. Jamil, S., Al Ani, M., \& Al Shubiri, F. (2015). The Effect of Working Capital Management Efficiency on the Operating Performance of the Industrial Companies in Oman. International Journal of Economics and Financial Issues, 5(4), 897-904. Retrieved from https://www.researchgate.net/ publication/282973034_The_Effect_of_Working_Capital_Management_Efficiency_on_the_Operating_Performance_of_the_Industrial_Companies_in_Oman

14. Kiptui, M. (2014). Determinants of Interest Rate Spread: Some Empirical Evidence from Kenya's Banking Sector. International 
Business Research, 7(11), 94107. https://doi.org/10.5539/ibr. v7n11p94

15. La Porta, R., Lopez-de-Silanes, F., \& Shleifer, A. (2008). The Economic Consequences of Legal Origin. Journal of Economic Literature, 46(2), 285-332. https:// doi.org/10.1257/jel.46.2.285

16. Maudos, J., \& Fernandez de Guevara, J. (2004). Factors explaining the interest margin in the banking sectors of the European Union. Journal of Banking and Finance, 28(9), 2259-2281. https://doi.org/10.1016/j.jbankfin.2003.09.004

17. Navneet, S., Boopen, S., Sawkut, R., Shalini, R., \& Binesh, R. (2009). Interest Rate Spread Determination in an Error Correction Model.

18. Naylah, M. (2010). Pengaruh Struktur Pasar Terhadap Kinerja Industri Perbankan Indonesia (Master's Thesis). Universitas Diponegoro.

19. Otoritas Jasa Keuangan (OJK). (2018). Statistik Perbankan Indonesia (SPI). Retrieved from https://www.ojk.go.id/id/kanal/ perbankan/data-dan-statistik/ statistik-perbankan-indonesia/ Documents/Pages/StatistikPerbankan-Indonesia---Desember-2018/SPI\%20Desember\%20 2018.pdf

20. Perez, P. (2011). Determinants of Interest Rate Spreads in Belize. Belmopan: Central Bank of Belize.
Retrieved from https://www. centralbank.org.bz/docs/defaultsource/4.5-conferences-andworking-papers/determinantsof-interest-rate-spreads-in-belize. pdf?sfvrsn $=4$

21. Raharjo, P., Hakim, D., Manurung, A. H., \& Maulana, T. (2014). Determinant of Capital Ratio: A Panel Data Analysis on State-Owned Banks in Indonesia. Buletin Ekonomi Moneter dan Perbankan, 16(4), 369-386. https:// doi.org/10.21098/bemp.v16i4.451

22. Sekaran, U., \& Bougie, R. (2013). Research Methods for Business: A Skill Building Approach (6th ed.). Chicherster, West Sussex: John Wiley \& Sons, Inc.

23. Shubiri, F. N. A., \& Jamil, S. A. (2017). Assessing the Determinants of Interest Rate Spread of Commercial Banks in Oman: An Empirical Investigation. European Research Studies Journal, XX(2A), 90-108. Retrieved from https://core.ac.uk/download/ pdf/155235531.pdf

24. Sidabalok, L. R., \& Viverita, V. (2011). The Determinants of Net Interest Margin in the Indonesia Banking Sector (Research Paper). https://doi.org/10.2139/ ssrn.1917367

25. Stewart, C., Matousek, R., \& Nguyen, T. (2015). Efficiency in the Vietnamese banking system: A DEA double bootstrap approach. Research in International
Business and Finance, 36, 96111. https://doi.org/10.1016/j. ribaf.2015.09.006

26. Tarmidzi, A., \& Kusumo, W. K. (2003). Analisis Rasio-Rasio Keuangan sebagai Indikator dalam Memprediksi Potensi Kebangkrutan Perbankan di Indonesia. Media Ekonomi dan Bisnis, 15(1), 54-75.

27. Tarus, D. K., Chekol, Y. B., \& Mutwol, M. (2012). Determinants of Net Interest Margins of Commercial Banks in Kenya: A Panel Study. Procedia Economics and Finance, 2, 199-208. http:// doi.org/10.1016/S22125671(12)00080-9

28. Valverde, S., \& Rodriguez-Fernandez, F. (2007). The determinants of bank margins in European banking. Journal of Banking and Finance, 31(7), 2043-2063. https://doi.org/10.1016/j.jbankfin.2006.06.017

29. Williams, B. (2007). Factors Determining Net Interest Margins in Australia: Domestic and Foreign Banks. Financial Markets, Institutions, and Instruments, 16(3), 145-165. https://doi.org/10.1111/j.14680416.2007.00122.x

30. Zhou, K., \& Wong, M. (2008). The Determinants of Net Interest Margins of Commercial Banks in Mainland China. Emerging Markets Finance and Trade, 44(5), 41-53. https://doi.org/10.2753/ REE1540-496X440503 